\title{
Earthworm Castings as a Substrate for Poinsettia Production
}

\author{
Pablo R. Hidalgo ${ }^{1}$ and Richard L. Harkess ${ }^{2}$ \\ Department of Plant and Soil Sciences, Box 9555, 117 Dorman Hall, \\ Mississippi State University, Mississippi State, MS 39762
}

Additional index words. Euphorbia pulcherrima, vermicompost, peatmoss, growth index, foliar and bract area, dry weight, root development, animal waste, horse manure, cattle manure, sheep manure

\begin{abstract}
Experiments were conducted to evaluate earthworm castings (vermicompost) as a substrate for poinsettia (Euphorbia pulcherrima Willd.) 'Freedom Red' production. Vermicomposts produced from sheep, cattle, or horse manures were mixed at different ratios with 70 peatmoss : 30 perlite (v/v) to create 13 substrates. Chemical and physical properties were measured on all substrates used. Growth index, foliar and bract area, and dry weight were greater on plants grown in substrates with castings from sheep or cattle manure. These castings had greater initial nutrient content than the castings from horse manure. Mixtures of castings and peat produced better plant responses than castings alone. Better plant responses were sometimes associated with values outside the recommended $\mathrm{pH}$ and electrical conductivity levels for poinsettia production. The highest values obtained for growth index, foliar and bract area, dry weight, and root development were produced in the substrates with moderate pore space or water holding capacity. Substrates with greater air space produced plants with greater dry weight and root development than substrates with less air space. The highest quality plants were grown in substrates with $25 \%$ castings from sheep or cattle manures.
\end{abstract}

Poinsettia(Euphorbia pulcherrima Willd.) is the number one selling potted plant in the United States. An important factor for container production is the container substrate in which the plants are grown because a healthy plant depends on the development of a functional root system (Bilderback, 1982). Artificial, or soilless, substrates are used extensively in the production of containerized greenhouse and nursery crops including poinsettias (Konduru and Evans, 1999). The selection of an effective growth substrate is important to produce a quality poinsettia (Barnes et al., 1994). When growing poinsettias, the most important feature of the growth substrate used is that it must be clean, reproducible, and have appropriate physical properties for root development (Hartley, 1992). Independent of the origin, the substrate used should also be light in weight, porous, well-drained, possess a moderate nutrient content, and be easy to manage (Tayama and Roll, 1990). Poinsettias

Received for publication 1 Feb. 2001. Accepted for publication 13 Aug. 2001. This paper is a portion of the dissertation submitted by P.H. in partial fulfillment of the requirements for the Ph.D. degree at Mississippi State Univ. We thank the Paul Ecke Ranch (Encinitas, Calif.) for the donation of the plant material used in this research. Contribution of the Mississippi Agricultural and Forestry Experiment Station journal article no. J9798. Mention of trademark or proprietary product does not constitute a guarantee or warranty of the product and does not imply its approval to the exclusion of other products that may also be suitable.

'Graduate Research Assistant.E-mail address:prh4@ ra.msstate.edu

${ }^{2}$ Associate Professor. To whom reprint requests should be addressed. E-mail address: harkessr@ ra.msstate.edu grown in a highly porous growing substrate will produce optimum shoot and root growth (Pertuit and Mazur, 1981). Hartley (1992) reported that mixtures of peat and perlite, vermiculite or processed wood bark and containing at least $50 \%$ sphagnum peat can be used to grow poinsettias. Peatmoss is the most desirable form of organic matter to include in a poinsettia growth substrate (Barnes et al., 1994; Tomati et al., 1993), but it is becoming increasingly expensive or unavailable (Garrison, 1995; Sanderson and Martin, 1974). As a result, greenhouses are looking for alternatives to the substrates currently used: mixtures of peat, pine bark, vermiculite, and perlite.

Although peatmoss is the preferred substrate for poinsettia production, it has several distinct disadvantages. Peatmoss is found in wetland ecosystems and the public and scientific community are concerned about the negative environmental impact of harvesting peat (Barber, 1993; Barkham, 1993; Buckland, 1993; Edwards and Fletcher, 1988). One way to reduce or stop peatmoss harvesting for container plant production is to find an acceptable alternative with similar characteristics (Garrison, 1995; Sanderson and Martin, 1974). An alternative substrate may present additional advantages over peatmoss since peatmoss supplies can be limited when weather conditions restrict harvest. Peatmoss quality also often varies, depending on source (McConnell et al., 1972). Peatmoss can be difficult to re-wet after it dries. When wet for prolonged periods of time, it can be a favorable growth medium for fungal pathogens (Knauss, 1996). Additionally, new substrate components may offer better conditions for plant growth and at the same time reduce plant production costs when compared to peatmoss (Stamps and Evans, 1999).

Much research has concentrated on the use of municipal or agricultural wastes for horticultural production. These materials have the disadvantage of composition variability, limited or inconsistent availability, and containing undesirable components such as glass, metal fragments, lead, and mercury that make them difficult to work with (Konduru and Evans, 1999). Among these organic materials, livestock manure has been used on agricultural land for centuries and is considered to contain an adequate amount of available phosphorus (Wen et al., 1997). Among all organic wastes, earthworms have shown a preference for animal manures (Laird and Kroger, 1981). Vermicompost production can be profitable and at the same time decrease the environmental impact of animal wastes (Edwards and Fletcher, 1988). Edwards (1988) reported that Eisenia fetida is the most common species used on organic wastes for vermicomposting purposes. Digestion of organic wastes by earthworms with the consequent production of vermicompost can generate an alternative substrate for horticultural industries (Grapelli et al.,1985). The use of vermicompost in horticulture is based on growth improvement for plants when compared to the regular substrates used, compatibility with technology in use, and low cost of production (Tomati et al., 1993).

In this study, worm castings produced from sheep, cattle, and horse manures were combined in different ratios with a peatmoss and perlite base substrate. The objectives were to determine if vermicompost is a suitable substrate for poinsettia production and to determine whether there is a significant difference in plant growth due to source of organic material used in vermicompost production.

\section{Materials and Methods}

Castings produced using the red or tiger earthworm, Eisenia fetida, feeding on sheep, cattle, or horse manures were used to create the different substrates evaluated in this experiment. Horse and $75 \%$ of the cattle manure (by volume) were harvested from fields of grazing animals feeding on grass, and were vermicomposted without any pretreatment. Sheep and $25 \%$ of the cattle manure, collected from stables from animals feeding on concentrated feed supplements and hay, were leached with water twice, left for $4 \mathrm{~d}$ and leached again three times to reduce the amount of salt and ammonia present in these manures. Edwards (1988) pointed out that earthworms are very sensitive to ammonia and will not survive in organic wastes containing high amounts of ammonia. Edwards also reported that earthworms will die when high amounts of inorganic salts are present in the waste, but both excessive ammonia and salts can be washed out of the waste. To this respect, cattle and horse manures used in this experiment had an average electrical conductivity (EC) of 1.25 and 0.90 $\mathrm{dS} \cdot \mathrm{m}^{-1}$, respectively, while sheep manure readings were around $13.0 \mathrm{dS} \cdot \mathrm{m}^{-1}$ before leaching. 
Five liters of manure and $170 \mathrm{~g}$ of mostly adult earthworms $(\approx 425$ specimens $)$ were placed in a 6.9-L plastic container. The containers were placed in shade to ensure favorable temperature and light for earthworm growth (Edwards, 1988). Each manure was replicated 16 times for a total of 48 plastic containers used in the production of castings. About 1 month was needed for the worms to consume the manure and produce the castings.

After 1 month, the worms were removed and the 16 replications of each casting were combined, air-dried, and passed through a 6mm sieve through which $\approx 90 \%$ of the castings passed. Twelve substrate treatments were obtained by mixing [ 70 peatmoss : 30 perlite $(\mathrm{v} / \mathrm{v})(\mathrm{PP})]$ and casting from each of the three animal manures at $0: 1,1: 3,1: 1$, or 3:1 ratios. No lime or other amendments were added to any of the substrate treatments. A thirteenth treatment, $100 \%$ PP with no lime or fertilizer amendments was used as the control.

Initial bulk density, percent pore space, percent air space, water-holding capacity, electrical conductivity (EC), and $\mathrm{pH}$ of the different substrates were determined using 3 samples of each treatment substrate. EC and $\mathrm{pH}$ were analyzed using a 1:2 dilution. Single samples of the castings and control substrate were delivered to the Mississippi State Univ. Soil Testing Laboratory (Mississippi State, Miss.) to determine macro and micronutrient content (Cox, 2001).

Single rooted cuttings of 'Freedom Red' poinsettia (Paul Ecke Poinsettias, Encinitas, Calif.) were transplanted to 1-L(15 cm diameter) plastic pots on 4 Sept. 1998 and grown in a polyethylene covered greenhouse. A night interruption of continuous light from 22:00 to 02:00 HR was used until the start of short days, 7 Oct. The plants were irrigated as needed. The plants were pinched on 17 Sept. to leave six leaves. All plants in the experiment were fertilized using Peter's 15N-2.15P-20.75K Poinsettia Peat-lite Special (The Scotts Co., Marysville, Ohio) at $200 \mathrm{mg} \cdot \mathrm{L}^{-1} \mathrm{~N}$ by fertigation any time water was needed, but only tap water was applied during weekends. A tank mix of B-Nine $\left(2500 \mathrm{mg} \cdot \mathrm{L}^{-1}\right.$ ) (Uniroyal Chemical Co., Middlebury, Conn.) and Cycocel (1500 mg. $\left.\mathrm{L}^{-1}\right)$ (Olympic Horticultural Products, Mainland, Pa.) was applied on 13 Oct. for height control.

Every 2 weeks, leachate samples were collected from each plant $1 \mathrm{~h}$ after irrigation using the Virginia Tech pour-through technique (Wright, 1986). Leachate $\mathrm{pH}$ and EC were measured by using an Accumet Basic pH Meter (Fisher Scientific, Springfield, N.J.) and a YSI model 35 Conductance Meter (Yellow Springs Instruments, Yellow Springs, Ohio), respectively.

At each date of leachate collection, height (h) was measured for each plant from the substrate surface to the shoot apex of the tallest branch. Width (w1) was measured across the side that appeared to be widest, the plant was turned $90^{\circ}$ and a second measurement (w2) was taken. Using these measurements, the growth index was calculated as:
Growth Index $=\pi \cdot\{[(w 1+w 2) / 2] / 2\}^{2} \cdot h$

(i.e., a volume estimate).

At anthesis, leaf and bract surface area, root development, depth of substrate, and plant dry weight were determined. Anthesis was determined as pollen shed in at least two of the inflorescences. Total foliar and bract area were determined using a LI-COR portable area meter (model LI-3000; LI-COR, Lincoln, Nebr.).

Root development was scored using a visual scale from 1 to 5 , where $1=$ roots covering $<20 \%$ of substrate (area in contact with the pot), 2 = roots covering $20 \%$ to $40 \%$ of substrate, $3=$ roots covering $40 \%$ to $60 \%$ of substrate, $4=$ roots covering $60 \%$ to $80 \%$ of substrate, and $5=$ roots covering $>80 \%$ of substrate. Depth of substrate was calculated by measuring from the bottom of the pot to the surface of the substrate. Plant dry weight was measured by drying the leaves, bracts, and stems of each plant at $60^{\circ} \mathrm{C}$ until dry and then weighing the plant.

The experiment was arranged in a completely randomized design using 13 treatments and 8 replications (eight plants per treatment). Data were analyzed using PROC GLM (SAS Statistical software, SAS Institute, Cary, N.C.). Treatment means were separated by Student Newman Keuls', 5\% significance level.

\section{Results and Discussion}

Substrates consisting of $0 \mathrm{PP}: 1$ castings (C) had greater macro and micronutrient content than the control (Table 1). The amount of each nutrient was proportionally reduced as the amount of peatmoss increased in the mixture for the three different castings evaluated (data not shown). All the casting substrates had greater nutrient content than the control.

Within casting type, bulk density was greatest at $0 \mathrm{PP}: 1 \mathrm{C}$ and decreased as the peat content increased (Table 2). Bulk density was greatest in the $0 \mathrm{PP}: 1$ sheep casting (SC) and horse casting (HC) substrates, followed by $1 \mathrm{PP}: 3 \mathrm{SC}$. All substrates with castings had a greater bulk density than the control (1 PP:0C). Among castings, $\mathrm{HC}$ at $1 \mathrm{PP}: 1 \mathrm{HC}$ had the most pore space. Mixing $\mathrm{HC}$ with peat reduced total pore space, but total pore space was similar at $1 \mathrm{PP}: 3 \mathrm{HC}$ and $1 \mathrm{PP}: 1 \mathrm{HC}$. Mixtures of $1 \mathrm{PP}: 3 \mathrm{HC}$ were similar in total pore space to those of $0 \mathrm{PP}: 1$ cattle castings (CC) and $1 \mathrm{PP}: 3 \mathrm{CC}$. The control (1 PP : $0 \mathrm{C}$ ) had the least total pore space of all other substrates used. The greatest percent air space was in the control substrate but was similar to mixtures of peat and any castings at $3 \mathrm{PP}: 1 \mathrm{C}$ or $1 \mathrm{PP}$ : 1 CC. Water- holding capacity, similar to bulk density, increased as the amount of castings increased. The greatest values for waterholding capacity occurred when substrates consisted of $100 \%$ castings (0 PP : $1 \mathrm{C}$ ). All the mixtures of PP : C had greater water-holding capacity than the control.

From 2 weeks after planting until anthesis, leachate $\mathrm{pH}$ from SC and HC substrates decreased as casting content decreased (Table 3 ). This trend was similar for CC substrates up to 8 weeks after planting when the $\mathrm{pH}$ among substrates with $100 \%$ or $75 \%$ castings was similar. This remained true until harvest. At all sample times, substrates with castings had a higher $\mathrm{pH}$ than the control. Castings obtained in our experiment had a high $\mathrm{pH}$ value similar to that of the original manures. Manures from sheep, cattle, and horse had average $\mathrm{pHs}$ equal to 7.9, 7.6, and 7.7, respectively. The control substrate had very low leachate $\mathrm{pH}$ readings as a result of no added lime amendments. Lime is normally included as an amendment in greenhouse substrates.

In all substrates containing castings, EC was greater than in the control leachate at all sample dates except weeks 10 and 12 when EC levels for leachates from the control and $3 \mathrm{PP}$ : 1 CC were similar (Table 4). From weeks 8 to 12 after transplant, EC of the leachate from the substrates formulated from SC and CC decreased as the amount of castings decreased in the substrate. In the leachate from the $1 \mathrm{PP}: 3$ $\mathrm{HC}$ substrate, EC levels were greater than in the substrate with $0 \mathrm{PP}: 1 \mathrm{HC}$ at $4,8,10$, and 12 weeks after planting.

Within castings type, poinsettia growth index was greatest and least for plants in substrates at $3 \mathrm{PP}: 1 \mathrm{C}$ and $0 \mathrm{PP}: 1 \mathrm{C}$, respectively at 2 weeks after pinching (Table 5). In SC and CC substrates, at 10 weeks after pinching, plants in $1 \mathrm{PP}: 3 \mathrm{C}$ were larger than the plants in $0 \mathrm{PP}: 1 \mathrm{C}$ or $3 \mathrm{PP}: 1 \mathrm{C}$ substrates. Within HC substrates, 0 PP : $1 \mathrm{HC}$ yielded the largest plants at 10 weeks. At 10 weeks after pinching, the controls were the smallest plants of all treatments except SC at 0:1 PP : SC. The limited growth of the plants in the control substrate was most likely the result of the low $\mathrm{pH}$ due to the lack of lime amendment.

During the first 4 weeks after pinching, plant growth index decreased as the amount of casting in the mixtures decreased (data not
Table 1. Nutrient content of earthworm castings and 70 peat : 30 perlite (v/v) used to grow poinsettia 'Freedom Red' plants. Single samples were used for each analysis.

\begin{tabular}{|c|c|c|c|c|c|c|c|c|c|c|}
\hline Substrates & $\mathrm{N}$ & $\mathrm{P}$ & $\mathrm{K}$ & $\mathrm{Ca}$ & $\mathrm{Mg}$ & $\mathrm{S}$ & $\mathrm{Fe}$ & $\mathrm{Mn}$ & $\mathrm{Zn}$ & $\mathrm{Cu}$ \\
\hline & --1 & -- & $\mathrm{mg} \cdot \mathrm{g}^{-1}$ & --- & -- & -- & -- & $-\mu$ & $5^{-1}-$ & -- \\
\hline $0 \mathrm{PP}: 1 \mathrm{SC}^{\mathrm{z}}$ & 35.2 & 13.7 & 12.3 & 30.2 & 7.2 & 1000 & 1711 & 314 & 215 & 10 \\
\hline $0 \mathrm{PP}: 1 \mathrm{CC}^{\mathrm{y}}$ & 45.4 & 14.3 & 7.4 & 61.6 & 11.1 & 1500 & 1285 & 380 & 337 & 40 \\
\hline $0 \mathrm{PP}: 1 \mathrm{HC}^{\mathrm{x}}$ & 39.1 & 9.5 & 8.3 & 18.5 & 5.6 & 860 & 1672 & 245 & 204 & 12 \\
\hline $1 \mathrm{PP}: 0 \mathrm{C}^{\mathrm{w}}$ & 14.3 & 0.1 & 0.1 & 2.5 & 0.9 & $0^{\mathrm{v}}$ & 668 & 22 & 78 & 2 \\
\hline
\end{tabular}

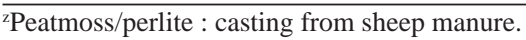

yPeatmoss/perlite : casting from cattle manure.

xeatmoss/perlite : casting from horse manure.

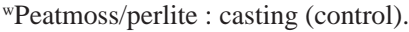

${ }^{\mathrm{v}}$ Content too low to accurately measure. 
Table 2. Physical properties of the substrates used to grow poinsettia 'Freedom Red'.

\begin{tabular}{|c|c|c|c|c|}
\hline Substrates & $\begin{array}{c}\text { Bulk density } \\
\left(\mathrm{kg} \cdot \mathrm{L}^{-1}\right)\end{array}$ & $\begin{array}{c}\text { Total pore space } \\
(\%)\end{array}$ & $\begin{array}{c}\text { Air space } \\
(\%)\end{array}$ & $\begin{array}{c}\mathrm{WHC}^{\mathrm{z}} \\
(\%)\end{array}$ \\
\hline $1 \mathrm{PP}: 1 \mathrm{SC}^{\mathrm{x}}$ & $0.24 \mathrm{a}^{\mathrm{y}}$ & $80.19 \mathrm{~b}$ & $10.33 \mathrm{de}$ & $69.85 \mathrm{~b}$ \\
\hline $1 \mathrm{PP}: 3 \mathrm{SC}$ & $0.20 \mathrm{~b}$ & $75.07 \mathrm{~d}$ & $9.73 \mathrm{e}$ & $65.33 \mathrm{~d}$ \\
\hline $1 \mathrm{PP}: 1 \mathrm{SC}$ & $0.16 \mathrm{~d}$ & $72.49 \mathrm{e}$ & $10.24 \mathrm{de}$ & $62.26 \mathrm{f}$ \\
\hline $3 \mathrm{PP}: 1 \mathrm{SC}$ & $0.12 \mathrm{f}$ & $71.49 \mathrm{e}$ & $12.80 \mathrm{ab}$ & $58.70 \mathrm{~h}$ \\
\hline $0 \mathrm{PP}: 1 \mathrm{CC}^{\mathrm{w}}$ & $0.16 \mathrm{~d}$ & $78.97 \mathrm{bc}$ & $8.23 \mathrm{f}$ & $70.74 \mathrm{~b}$ \\
\hline $1 \mathrm{PP}: 3 \mathrm{CC}$ & $0.15 \mathrm{e}$ & $78.27 \mathrm{c}$ & $10.47 \mathrm{de}$ & $67.80 \mathrm{c}$ \\
\hline $1 \mathrm{PP}: 1 \mathrm{CC}$ & $0.12 \mathrm{f}$ & $75.63 \mathrm{~d}$ & $11.90 a b c$ & $63.73 \mathrm{e}$ \\
\hline $3 \mathrm{PP}: 1 \mathrm{CC}$ & $0.10 \mathrm{~g}$ & $70.93 \mathrm{e}$ & $12.33 a b c$ & $58.59 \mathrm{~h}$ \\
\hline $0 \mathrm{PP}: 1 \mathrm{HC}^{\mathrm{v}}$ & $0.24 \mathrm{a}$ & $83.07 \mathrm{a}$ & $10.03 \mathrm{de}$ & $73.04 \mathrm{a}$ \\
\hline $1 \mathrm{PP}: 3 \mathrm{HC}$ & $0.19 \mathrm{c}$ & $79.08 \mathrm{bc}$ & $11.20 \mathrm{~cd}$ & $67.88 \mathrm{c}$ \\
\hline $1 \mathrm{PP}: 1 \mathrm{HC}$ & $0.16 \mathrm{~d}$ & $78.10 \mathrm{c}$ & $12.20 \mathrm{abc}$ & $65.90 \mathrm{~d}$ \\
\hline $3 \mathrm{PP}: 1 \mathrm{HC}$ & $0.12 \mathrm{f}$ & $72.11 \mathrm{e}$ & $11.74 \mathrm{bc}$ & $60.37 \mathrm{~g}$ \\
\hline $1 \mathrm{PP}: 0 \mathrm{C}^{\mathrm{u}}$ & $0.08 \mathrm{~h}$ & $67.59 \mathrm{f}$ & $13.08 \mathrm{a}$ & $54.51 \mathrm{i}$ \\
\hline
\end{tabular}

${ }^{2}$ Water-holding capacity

'Means in columns separated by Student-Newman-Keuls', 5\% significance level.

XPeatmoss/perlite : casting from sheep manure.

"Peatmoss/perlite : casting from cattle manure.

Peatmoss/perlite : casting from horse manure.

"Peatmoss/perlite : casting (control).

Table 3. Leachate $\mathrm{pH}$ of earthworm castings and peat/perlite substrates during growth of 'Freedom Red' poinsettia.

\begin{tabular}{lcccccc}
\hline \hline & \multicolumn{6}{c}{ No. of weeks after transplant } \\
\cline { 2 - 7 } Substrates & 2 & 4 & 6 & 8 & 10 & 12 \\
\hline 0 PP : 1 SC & $7.82 \mathrm{~b}^{2}$ & $7.64 \mathrm{a}$ & $7.60 \mathrm{a}$ & $7.46 \mathrm{a}$ & $7.30 \mathrm{bc}$ & $7.24 \mathrm{~b}$ \\
1 PP : 3 SC & $7.26 \mathrm{~d}$ & $7.26 \mathrm{~b}$ & $7.12 \mathrm{c}$ & $7.16 \mathrm{~b}$ & $7.03 \mathrm{de}$ & $7.08 \mathrm{~cd}$ \\
1 PP : 1 SC & $6.07 \mathrm{~g}$ & $6.27 \mathrm{e}$ & $6.49 \mathrm{e}$ & $6.70 \mathrm{~d}$ & $6.76 \mathrm{fg}$ & $6.70 \mathrm{e}$ \\
3 PP : 1 SC & $5.13 \mathrm{i}$ & $5.31 \mathrm{~g}$ & $5.72 \mathrm{~g}$ & $6.04 \mathrm{f}$ & $6.44 \mathrm{~h}$ & $6.19 \mathrm{f}$ \\
0 PP : 1 CC & $8.00 \mathrm{a}$ & $7.75 \mathrm{a}$ & $7.57 \mathrm{a}$ & $7.62 \mathrm{a}$ & $7.57 \mathrm{a}$ & $7.61 \mathrm{a}$ \\
1 PP : 3 CC & $7.46 \mathrm{c}$ & $7.36 \mathrm{~b}$ & $7.35 \mathrm{~b}$ & $7.51 \mathrm{a}$ & $7.52 \mathrm{ab}$ & $7.60 \mathrm{a}$ \\
1 PP : 1 CC & $6.50 \mathrm{f}$ & $6.56 \mathrm{~d}$ & $6.83 \mathrm{~d}$ & $7.08 \mathrm{~b}$ & $7.17 \mathrm{~cd}$ & $7.20 \mathrm{bc}$ \\
3 PP : 1 CC & $5.16 \mathrm{i}$ & $5.28 \mathrm{~g}$ & $5.64 \mathrm{~g}$ & $5.86 \mathrm{~g}$ & $6.34 \mathrm{~h}$ & $6.16 \mathrm{f}$ \\
0 PP : 1 HC & $7.31 \mathrm{~d}$ & $7.27 \mathrm{~b}$ & $7.23 \mathrm{bc}$ & $7.18 \mathrm{~b}$ & $7.10 \mathrm{cde}$ & $7.17 \mathrm{bc}$ \\
1 PP : 3 HC & $6.62 \mathrm{e}$ & $6.70 \mathrm{c}$ & $6.86 \mathrm{~d}$ & $6.86 \mathrm{c}$ & $6.91 \mathrm{ef}$ & $6.98 \mathrm{~d}$ \\
1 PP : 1 HC & $5.69 \mathrm{~h}$ & $5.89 \mathrm{f}$ & $6.15 \mathrm{f}$ & $6.35 \mathrm{e}$ & $6.55 \mathrm{gh}$ & $6.63 \mathrm{e}$ \\
3 PP : 1 HC & $4.69 \mathrm{j}$ & $4.70 \mathrm{~h}$ & $5.10 \mathrm{~h}$ & $5.14 \mathrm{~h}$ & $5.39 \mathrm{i}$ & $5.38 \mathrm{~g}$ \\
1 PP : 0 C & $3.85 \mathrm{k}$ & $4.26 \mathrm{i}$ & $4.37 \mathrm{i}$ & $4.44 \mathrm{i}$ & $4.92 \mathrm{j}$ & $4.69 \mathrm{~h}$ \\
\hline
\end{tabular}

${ }^{\mathrm{z}}$ Means in columns separated by Student-Newman-Keuls', $5 \%$ significance level.

'Peatmoss/perlite : casting from sheep manure.

Peatmoss/perlite : casting from cattle manure.

${ }^{w}$ Peatmoss/perlite : casting from horse manure.

${ }^{\vee}$ Peatmoss/perlite : casting (control).

shown). For the last observation, the greatest plant growth index was observed in the $1 \mathrm{PP}: 3 \mathrm{CC}$ substrate (Table 5). Growth indices of plants grown in $0 \mathrm{PP}: 1 \mathrm{CC}, 1 \mathrm{PP}: 1 \mathrm{CC}$, $1 \mathrm{PP}: 3 \mathrm{SC}$, and $0 \mathrm{PP}: 1 \mathrm{HC}$ were similar at week 10.

Plants in all substrates with castings had greater foliar area than those in the control (Table 5). Plants in all substrates, except 0:1 PP : SC, had greater bract area than those in the control substrate. Within SC substrate, plants in $0 \mathrm{PP}$ : $1 \mathrm{SC}$ had the least foliar and bract area while bract area was greatest for poinsettias in substrates with $1 \mathrm{PP}: 3 \mathrm{SC}$ and $1 \mathrm{PP}: 1 \mathrm{SC}$. The addition of peat to the CC resulted in increased poinsettia foliar area (Table 5). However, bract area was least on plants grown in $3 \mathrm{PP}: 1 \mathrm{CC}$. Foliar area was greatest among plants in the $\mathrm{HC}$ substrates when mixed at $3 \mathrm{PP}: 1 \mathrm{HC}$. Bract area was less on poinsettias in $1 \mathrm{PP}: 1 \mathrm{HC}$ than those in $0 \mathrm{PP}: 1 \mathrm{HC}$ or $1 \mathrm{PP}: 3 \mathrm{HC}$. Substrates with $1 \mathrm{PP}$ : $3 \mathrm{CC}$ produced plants with greater foliar area than in any substrate containing SC or $\mathrm{HC}$. Compared to $1 \mathrm{PP}: 3 \mathrm{CC}$, poinsettia bract area was similar among plants in $0 \mathrm{PP}$ : $1 \mathrm{CC}$ and $1 \mathrm{PP}: 3 \mathrm{SC}$ (Table 5). These three substrates yielded greater bract area than all the $\mathrm{HC}$ substrates. Bract area was greater for plants in $0 \mathrm{PP}: 1 \mathrm{CC}, 1 \mathrm{PP}: 3 \mathrm{CC}$, and $1 \mathrm{PP}$ : $1 \mathrm{CC}$; and at $1 \mathrm{PP}: 3 \mathrm{SC}$ and $1 \mathrm{PP}: 1 \mathrm{SC}$ than any other substrate (Table 5). Plants in $3 \mathrm{PP}$ : $1 \mathrm{SC}$ and $3 \mathrm{PP}$ : $1 \mathrm{CC}$ substrates had similar bract area to plants grown in $0 \mathrm{PP}: 1 \mathrm{HC}$, $1 \mathrm{PP}: 3 \mathrm{HC}$, and $3 \mathrm{PP}: 1 \mathrm{HC}$. Bract area of plants grown in $1 \mathrm{PP}: 1 \mathrm{HC}$ or $3 \mathrm{PP}: 1 \mathrm{HC}$ were similar.

Within each casting type, in general, root development was greater when plants were grown in substrates consisting of $\geq 3 \mathrm{PP}: 1 \mathrm{C}$ (Table 5). Within CC substrates, plants in 0 PP : 1 CC had the least root development, whereas those in $\mathrm{HC}$ substrates, $1 \mathrm{PP}: 1 \mathrm{HC}$, $1 \mathrm{PP}: 3 \mathrm{HC}$, and $0 \mathrm{PP}: 1 \mathrm{HC}$ all had reduced root development. The greatest root development was found in those substrates that had increased air space and decreased water holding capacity (Tables 2 and 6). However, these substrates also had lower total pore space. The decrease in root development with increase in casting appeared correlated to increased bulk density, leachate $\mathrm{pH}$, and $\mathrm{EC}$ as casting content increased (Tables 2, 3, and 4). However, better root development seemed unrelated to greater foliar or bract area.

Increased plant dry weight was associated with a greater amount of peat in the mixture, but one of the two lowest plant dry weights was observed in the substrate consisting of $100 \%$ PP (Table 5). Plant dry weight in substrates with 0:1 PP : SC were similar to those in the control substrate and was greatly reduced compared to those of plants in all other formulations. Bulk density of 0 PP : 1 SC was one of the greatest (Table 2). In CC substrates, plants in $0 \mathrm{PP}$ : $1 \mathrm{CC}$ had the lowest dry weight followed by the plants in $1 \mathrm{PP}: 3 \mathrm{CC}$ (Table 5). These substrates also produced plants with the greatest growth index and bract area, whereas $1 \mathrm{PP}: 3 \mathrm{CC}$ produced plants with the greatest foliar area. The largest growth index but lowest dry weight observed in these plants could indicate greater cell enlargement without an increase in photosynthate accumulation in those plants grown in such substrates. All plants grown in substrates with $\mathrm{HC}$ had dry weights less than those in substrates with $3 \mathrm{PP}$ : $1 \mathrm{SC}$ or $1 \mathrm{PP}: 1 \mathrm{CC}$ and $3 \mathrm{PP}: 1 \mathrm{CC}$.

As castings content increased, substrate shrinkage increased (data not shown). The 0 PP : 1 CC substrate shrank more than any other substrate. This pattern of shrinkage was similar to the decrease in root growth also observed with increased casting content (Table 5). While shrinkage was greatest in the HC substrates, within substrate type, a similar trend to increased growth with a decrease in castings was observed. Therefore, growth differences were not likely due to possible changes in physical properties from substrate shrinkage but to the initial physical and chemical properties of the substrates.

Greatest values of growth index, foliar and bract area, and dry weight were obtained in mixtures with castings from sheep and cattle manure. Only bract area, in plants grown in $0 \mathrm{PP}: 1 \mathrm{CC}$, was as good or better than in plants grown in mixtures of peat and castings (Table 5). Foliar and bract area as well as dry weight of plants grown in mixtures of PP : SC were $>0$ PP : 1 SC. Foliar area and dry weight were higher for $\mathrm{CC}$ when mixtures between it and peat were used than when $\mathrm{CC}$ was used alone. Both castings from cattle and sheep manures had higher initial values for most of the nutrients evaluated than castings from horse manure (Table 1). Greater initial nutrient concentrations may have provided better conditions for growth. During the earthworm digestion, nutrients bound in the organic form $(\mathrm{N}, \mathrm{P}, \mathrm{S})$ have been shown to be mineralized and made more available to the plant (Coleman et al., 1983; Richard, 1974). There was a proportional decrease in initial nutrient content due to dilution with the addition of peat. Plants did not grow as large in $100 \%$ castings as in substrates where peat was added. Since initial amount of nutrients in the substrates and the different growth parameters evaluated were apparently 
Table 4. Leachate electrical conductivity $\left(\mathrm{dS} \cdot \mathrm{m}^{-1}\right)$ of earthworm casting and peat/perlite substrates during growth of 'Freedom Red' poinsettia plants.

\begin{tabular}{|c|c|c|c|c|c|c|}
\hline \multirow[b]{2}{*}{ Substrates } & \multicolumn{6}{|c|}{$\begin{array}{c}\text { Leachate electrical conductivity }\left(\mathrm{dS} \cdot \mathrm{m}^{-1}\right) \\
\text { No. of weeks after transplant }\end{array}$} \\
\hline & 2 & 4 & 6 & 8 & 10 & 12 \\
\hline $0 \mathrm{PP}: 1 \mathrm{SC}^{\mathrm{y}}$ & $3.44 \mathrm{a}^{z}$ & $1.83 \mathrm{bcd}$ & $1.50 \mathrm{~b}$ & $1.07 \mathrm{ab}$ & $0.93 \mathrm{a}$ & $0.81 \mathrm{a}$ \\
\hline $1 \mathrm{PP}: 3 \mathrm{SC}$ & $3.24 \mathrm{a}$ & $1.83 \mathrm{bcd}$ & $1.47 \mathrm{bc}$ & $1.02 \mathrm{abc}$ & $0.75 \mathrm{~b}$ & $0.65 b c$ \\
\hline $1 \mathrm{PP}: 1 \mathrm{SC}$ & $2.63 \mathrm{bc}$ & $2.12 \mathrm{~b}$ & $1.29 \mathrm{bcd}$ & $0.83 \mathrm{~d}$ & $0.52 \mathrm{~d}$ & $0.48 \mathrm{de}$ \\
\hline $3 \mathrm{PP}: 1 \mathrm{SC}$ & $3.32 \mathrm{a}$ & $1.71 \mathrm{~cd}$ & $0.61 \mathrm{e}$ & $0.39 \mathrm{e}$ & $0.27 \mathrm{ef}$ & $0.24 \mathrm{f}$ \\
\hline $0 \mathrm{PP}: 1 \mathrm{CC}^{\mathrm{x}}$ & $3.26 \mathrm{a}$ & $2.60 \mathrm{a}$ & $1.78 \mathrm{a}$ & $1.18 \mathrm{a}$ & $0.71 \mathrm{bc}$ & $0.57 \mathrm{~cd}$ \\
\hline $1 \mathrm{PP}: 3 \mathrm{CC}$ & $3.03 \mathrm{ab}$ & $1.96 \mathrm{~b}$ & $1.48 \mathrm{~b}$ & $0.83 \mathrm{~cd}$ & $0.52 \mathrm{~d}$ & $0.43 \mathrm{e}$ \\
\hline $1 \mathrm{PP}: 1 \mathrm{CC}$ & $3.23 \mathrm{a}$ & $2.69 \mathrm{a}$ & $1.42 \mathrm{bc}$ & $0.77 \mathrm{~d}$ & $0.56 \mathrm{~d}$ & $0.47 \mathrm{de}$ \\
\hline $3 \mathrm{PP}: 1 \mathrm{CC}$ & $3.23 \mathrm{a}$ & $1.70 \mathrm{~cd}$ & $0.65 \mathrm{e}$ & $0.45 \mathrm{e}$ & $0.23 \mathrm{fg}$ & $0.21 \mathrm{fg}$ \\
\hline $0 \mathrm{PP}: 1 \mathrm{HC}^{\mathrm{w}}$ & $2.62 \mathrm{bc}$ & $1.53 \mathrm{de}$ & $1.16 \mathrm{~d}$ & $0.87 \mathrm{~cd}$ & $0.61 \mathrm{~cd}$ & $0.49 \mathrm{de}$ \\
\hline $1 \mathrm{PP}: 3 \mathrm{HC}$ & $2.32 \mathrm{c}$ & $2.12 \mathrm{~b}$ & $1.29 \mathrm{bcd}$ & $1.11 \mathrm{ab}$ & $0.82 \mathrm{ab}$ & $0.70 \mathrm{~b}$ \\
\hline $1 \mathrm{PP}: 1 \mathrm{HC}$ & $2.22 \mathrm{c}$ & $1.81 \mathrm{bcd}$ & $1.24 \mathrm{~cd}$ & $0.96 \mathrm{bcd}$ & $0.61 \mathrm{~cd}$ & $0.49 \mathrm{de}$ \\
\hline $3 \mathrm{PP}: 1 \mathrm{HC}$ & $1.46 \mathrm{~d}$ & $1.27 \mathrm{e}$ & $0.65 \mathrm{e}$ & $0.53 \mathrm{e}$ & $0.38 \mathrm{e}$ & $0.25 \mathrm{f}$ \\
\hline $1 \mathrm{PP}: 0 \mathrm{C}^{\mathrm{v}}$ & $0.64 \mathrm{e}$ & $0.25 \mathrm{f}$ & $0.25 \mathrm{f}$ & $0.23 \mathrm{f}$ & $0.14 \mathrm{~g}$ & $0.12 \mathrm{~g}$ \\
\hline
\end{tabular}

${ }^{2}$ Means in columns separated by Student-Newman-Keuls', 5\% significance level.

yeatmoss/perlite : casting from sheep manure.

${ }^{x}$ Peatmoss/perlite : casting from cattle manure.

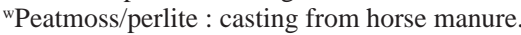

"Peatmoss/perlite : casting (control).

Table 5. Growth and development of 'Freedom Red' poinsettia produced in earthworm casting and peat/perlite substrates.

\begin{tabular}{|c|c|c|c|c|c|c|}
\hline \multirow[b]{2}{*}{ Substrates } & \multicolumn{2}{|c|}{$\begin{array}{l}\text { Growth index }{ }^{2}\left(\mathrm{~cm}^{3}\right) \\
\text { weeks after pinching }\end{array}$} & \multirow{2}{*}{$\begin{array}{l}\text { Foliar area } \\
\left(\mathrm{cm}^{2}\right)\end{array}$} & \multirow{2}{*}{$\begin{array}{l}\text { Bract area } \\
\left(\mathrm{cm}^{2}\right)\end{array}$} & \multirow{2}{*}{$\begin{array}{l}\text { Dry wt } \\
(\mathrm{g})\end{array}$} & \multirow{2}{*}{$\begin{array}{c}\text { Root } \\
\text { development }\end{array}$} \\
\hline & 2 & 10 & & & & \\
\hline$\overline{1 \mathrm{PP}: 1 \mathrm{SC}^{\mathrm{w}}}$ & $250 \mathrm{f}^{\mathrm{y}}$ & $14598 \mathrm{hi}$ & $1137.9 \mathrm{f}$ & $1674.7 \mathrm{e}$ & $11.68 \mathrm{~g}$ & $2.0 \mathrm{~g}$ \\
\hline $1 \mathrm{PP}: 3 \mathrm{SC}$ & $877 \mathrm{e}$ & $33048 \mathrm{bc}$ & $1855.3 \mathrm{bc}$ & $3478.6 \mathrm{ab}$ & $20.80 \mathrm{cde}$ & $2.6 \mathrm{ef}$ \\
\hline $1 \mathrm{PP}: 1 \mathrm{SC}$ & $1550 \mathrm{~cd}$ & $28823 \mathrm{~cd}$ & $1771.1 \mathrm{~cd}$ & $3201.2 \mathrm{~b}$ & $21.81 \mathrm{~cd}$ & $3.8 \mathrm{~b}$ \\
\hline $3 \mathrm{PP}: 1 \mathrm{SC}$ & 2977 a & $26184 \mathrm{de}$ & $1788.7 \mathrm{bc}$ & $2661.7 \mathrm{c}$ & $25.39 \mathrm{ab}$ & $4.8 \mathrm{a}$ \\
\hline $0 \mathrm{PP}: 1 \mathrm{CC}^{\mathrm{v}}$ & 630 ef & $33556 \mathrm{~b}$ & $1735.0 \mathrm{~cd}$ & $3363.5 \mathrm{ab}$ & $19.29 \mathrm{def}$ & $2.4 \mathrm{fg}$ \\
\hline $1 \mathrm{PP}: 3 \mathrm{CC}$ & $1566 \mathrm{~cd}$ & $40419 a$ & $2075.2 \mathrm{a}$ & $3711.0 \mathrm{a}$ & $23.30 \mathrm{bc}$ & $3.3 \mathrm{bcd}$ \\
\hline $1 \mathrm{PP}: 1 \mathrm{CC}$ & $2302 \mathrm{~b}$ & $30422 \mathrm{bcd}$ & $1988.9 \mathrm{ab}$ & $3264.9 \mathrm{~b}$ & $26.40 \mathrm{a}$ & $3.6 \mathrm{bc}$ \\
\hline $3 \mathrm{PP}: 1 \mathrm{CC}$ & $2953 \mathrm{a}$ & 22029 efg & $1988.4 \mathrm{ab}$ & $2691.2 \mathrm{c}$ & $26.40 \mathrm{a}$ & $4.8 \mathrm{a}$ \\
\hline $0 \mathrm{PP}: 1 \mathrm{HC}^{\mathrm{u}}$ & $226 \mathrm{f}$ & $29438 \mathrm{bcd}$ & $1337.4 \mathrm{ef}$ & $2578.1 \mathrm{c}$ & $17.09 \mathrm{f}$ & $3.0 \mathrm{de}$ \\
\hline $1 \mathrm{PP}: 3 \mathrm{HC}$ & $658 \mathrm{ef}$ & $22625 \mathrm{ef}$ & $1363.9 \mathrm{e}$ & $2580.3 \mathrm{c}$ & 18.29 ef & $3.1 \mathrm{cde}$ \\
\hline $1 \mathrm{PP}: 1 \mathrm{HC}$ & $991 \mathrm{e}$ & $17647 \mathrm{gh}$ & $1369.3 \mathrm{e}$ & $2150.1 \mathrm{~d}$ & 20.74 cde & $3.5 \mathrm{bcd}$ \\
\hline $3 \mathrm{PP}: 1 \mathrm{HC}$ & $1889 \mathrm{bc}$ & $18363 \mathrm{fgh}$ & $1580.1 \mathrm{~d}$ & $2387.0 \mathrm{~cd}$ & 20.48 cde & $4.4 \mathrm{a}$ \\
\hline $1 \mathrm{PP}: 0 \mathrm{C}^{\mathrm{t}}$ & $1141 \mathrm{de}$ & $10866 \mathrm{i}$ & $861.0 \mathrm{~g}$ & $1560.5 \mathrm{e}$ & $12.53 \mathrm{~g}$ & $4.6 \mathrm{a}$ \\
\hline
\end{tabular}

${ }^{\mathrm{z}} \mathrm{GI}=\pi \cdot\{[(\mathrm{w} 1+\mathrm{w} 2) / 2] / 2\}^{2} \cdot \mathrm{h}$

${ }^{y}$ Means in columns separated by Student-Newman-Keuls', $5 \%$ significance level.

${ }^{\mathrm{x}} 1=$ roots covered $<20 \%$ of substrate (area in contact with the pot); $2=$ roots covering $20 \%$ to $40 \%$ of substrate; $3=$ roots covering $40 \%$ to $60 \%$ of substrate; $4=$ roots covering $60 \%$ to $80 \%$ of substrate; and $5=$ roots covering more than $80 \%$ of substrate.

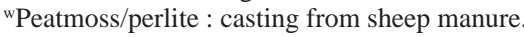

"Peatmoss/perlite : casting from cattle manure.

"Peatmoss/perlite : casting from horse manure.

'Peatmoss/perlite : casting (control).

unrelated, other substrate characteristics must be considered.

The optimum $\mathrm{pH}$ range for nutrient availability in soilless substrates is generally lower than for field soils, being $\approx 5.0$ to 5.5 or 6.5 (Nelson, 1991). Poinsettia grows best in soilless substrates with a $\mathrm{pH}$ range between 5.8 and 6.3 (Dole and Wilkins, 1999). Mixtures at the ratios $3 \mathrm{PP}: 1 \mathrm{SC}, 3 \mathrm{PP}: 1 \mathrm{CC}$, and $1 \mathrm{PP}: 1 \mathrm{HC}$ are the only substrates with values in that range (Table 3). The rest of the mixtures tended to have a higher $\mathrm{pH}$ with a few exceptions of $\mathrm{pH}$ values $<5.6$. In our experiment, the greater plant growth index values were produced in substrates with the $\mathrm{pH}$ values above those recommended for poinsettia production. Barley (1961) considered that the increased $\mathrm{pH}$ of earthworm castings was responsible for a higher solubility of nutrients and thus increased availability.

When plants were grown in mixtures with
SC, some of the highest values for foliar area, dry weight, and root development were obtained in the mixtures with the lower electrical conductivity values. For those plants grown in CC mixtures, foliar area, bract area, dry weight, and root development were greater in those mixtures containing peat. Root development on plants grown in HC substrates was also greater in substrates with the lowest EC values. Plants grown in $3 \mathrm{PP}: 1 \mathrm{HC}$ produced the greatest root development. These root development results were similar to those obtained with the control substrate which had the least electrical conductivity of all the substrates tested. Castings have been reported to stimulate root initiation, root elongation, and root biomass of ornamental plants with the best results obtained when castings alone were used (Grapelli et al., 1985). However, in this study the opposite was observed since root development decreased as the amount of castings increased.

Nelson (1991) reported that an EC level of 2 to $4 \mathrm{dS} \cdot \mathrm{m}^{-1}$ is suitable for most greenhouse crops, and a lower level, 0.75 or lower, is better for very young plants or rooted cuttings. The best range to grow poinsettia plants of the Freedom family is reported to be between 1.5 and $2 \mathrm{dS} \cdot \mathrm{m}^{-1}$ (Hartley, 1998 personal communication). Substrates with $25 \%$ casting had decreased electrical conductivity levels earlier in production, possibly explaining the greater growth index values at harvest.

Air space increased when the amount of casting decreased in the substrate. Dry weight and root development followed the same trend. Bulk density, pore space, and waterholding capacity showed the opposite trend. The greatest plant growth index, foliar/bract area, dry weight, and root development failed to coincide with the greatest bulk density, pore space, or water-holding capacity.

Comparing the results obtained with the peat:castings mixtures and the control, in general, all mixtures produced better results than the control. The poor growth of the plants in the control substrate was likely a result of the low substrate $\mathrm{pH}$. Poinsettias were larger when grown in $25 \%$ castings than when grown in a substrate with greater casting content. Castings from sheep and cattle manure yielded higher quality, larger poinsettias than castings from horse manure. High $\mathrm{pH}$ values associated with castings in the substrate, even above the values recommended for poinsettia production, did not have a detrimental effect on plant growth. The improved growth of plants in substrates with castings compared to the control may be due in part to the higher $\mathrm{pH}$ of substrates with castings. The addition of castings at $25 \%$ increased growth and bract development which improved plant quality. Plant growth was significantly affected by the source of organic matter used in vermicompost production. Castings were demonstrated to be a suitable substrate amendment for poinsettia production. Poinsettias produced in substrates with $25 \%$ castings from sheep or cattle manures were about twice as tall as the container they were grown in, had dark green foliage, and were of saleable quality.

\section{Literature Cited}

Barber, K. 1993. Peatlands as scientific archives of past biodiversity. Biodivers. Conserv. 1:474-489.

Barkham, J. 1993. For peat's sake: Conservation or exploitation? Biodivers. Conserv. 2:556-566.

Barley, K. 1961. Abundance of earthworms in agricultural land and their possible significance in agriculture. Adv. Agron. 13:249-268.

Barnes L., Drees, B., Hall, C., and Wilkerson, D. 1994. Texas poinsettia producers guide. Texas Agr. Ext. Serv. Texas A\&M Univ. System, College Station.

Bilderback, T. 1982. Container soils and soilless media. North Carolina Agr. Ext. Serv. NCPM No. 9, Raleigh, N.C.

Buckland, P. 1993. Peatland archaeology: A conservation resource on the edge of extinction. Biodivers. Conserv. 2:513-527. 
Coleman, D., Reid, C., and Cole, C. 1983. Biological strategies of nutrient cycling in soil systems. Adv. Ecol. Res. 13:1-53.

Cox, M.S. 2001. The Lancaster soil test method as an alternative to the Mehlich 3 soil test method. Soil Science. 166:484-489.

Dole, J. and Wilkins, H. 1999. Floriculture principles and species. Prentice Hall, Englewood Cliffs, N.J.

Edwards, C. 1988. Breakdown of animal vegetable and industrial organic wastes by earthworms, p. 21-23. In: C. Edwards and E. Neuhauser (eds.). Earthworms in waste and environmental management. Academic Publishing, The Hague, The Netherlands.

Edwards, C. and Fletcher, K. 1988. Interactions between earthworms and microorganisms in organic-matter breakdown. Agr. Ecosyst. Environ. 24:235-247.

Garrison, S. 1995. Development of potting soil mixes from local wastes. Sustainable Agriculture Research and Education/Agriculture in concert with the Environment (SARE/ACE, Annu. Rpt. PG95-25).
Grappeli, A., Tomati, U., Vergari, B., and Galli, E. 1985. Earthworm castings in plant propagation. HortScience 20:874-876.

Hartley, D. 1992. Poinsettias, p. 305-331. In: R.A. Larson (ed.). Introduction to floriculture. $2^{\text {nd }}$ ed. Academic, San Diego.

Knauss, J. 1996. A clear picture of an established and new growing media component for greenhouse culture. Georgia Floric. 6:22-23.

Konduru, S. and Evans, M. 1999. Coconut husk and processing effects on chemical and physical properties of coconut coir dust. HortScience 34:88-90.

Laird, J. and Kroger, M. 1981. Earthworms, anatomy, ecology, soil fertility, waste management. CRC Crit. Rev. Environ. Control 11:189218.

Mc Connell, D., Waters, W., and Poole, R. 1972. The chemical properties of several peat sources. Florida Foliage Growers 9:1-4.

Nelson, P. 1991. Greenhouse operation and management $4^{\text {th }}$ ed. Prentice-Hall, Upper Saddle River, N.J.

Pertuit, A. and Mazur, A. 1981. Development of growth media for poinsettias. HortScience 16:216-218.

Richard, B. 1974. Introduction to the soil ecosystem. Longman, New York.

Sanderson, K. and Martin, W. 1974. Performance of woody ornamentals in municipal compost medium under nine fertilizer regimes. HortScience 9:242-243.

Stamps, R. and Evans, M. 1999. Growth of Dracaena marginata and Spathiphyllum 'Petite' in sphagnum peat- and coconut coir dust-based growing media. J. Environ. Hort. 17:49-52.

Tayama, H. and T. Roll. 1990. Tips on growing poinsettias. 2nd Ed. Ohio Coop. Ext. Serv. Ohio State Univ., Columbus.

Tomati, U., Galli, E., and Buffone, R. 1993. Compost in floriculture. Acta Hort. 342:175-181.

Wen, G., Bates, T., Voroney, R., Winter, J., and Schellenbert, M. 1997. Comparison of phosphorus availability with application of sewage sludge, sludge compost, and manure compost. Comm. Soil Sci. Plant Annu. 28:1481-1497.

Wright, R. 1986. The pour through nutrient extraction procedure. HortScience 21:227-229. 